\title{
'Here one moment, gone the next': A framework for liquid communication generated through social media platforms in the Botswana public sector
}

\begin{tabular}{|c|c|}
\hline \multicolumn{2}{|c|}{$\begin{array}{l}\text { Authors: } \\
\text { Tshepho Mosweu } \\
\text { Mpho Ngoepe }\end{array}$} \\
\hline \multicolumn{2}{|c|}{ 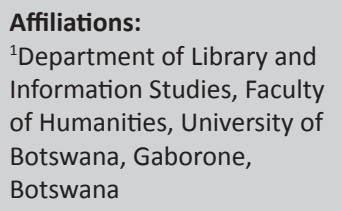 } \\
\hline \multicolumn{2}{|c|}{$\begin{array}{l}{ }^{2} \text { Department of Information } \\
\text { Science, School of Arts, } \\
\text { College of Human Sciences, } \\
\text { University of South Africa, } \\
\text { Pretoria, South Africa }\end{array}$} \\
\hline \multicolumn{2}{|c|}{$\begin{array}{l}\text { Project research number: } \\
105739\end{array}$} \\
\hline \multicolumn{2}{|c|}{$\begin{array}{l}\text { Corresponding author: } \\
\text { Mpho Ngoepe, } \\
\text { ngoepms@unisa.ac.za }\end{array}$} \\
\hline \multicolumn{2}{|c|}{$\begin{array}{l}\text { Dates: } \\
\text { Received: } 14 \text { Feb. } 2019 \\
\text { Accepted: } 05 \text { July } 2019 \\
\text { Published: } 28 \text { Aug. } 2019\end{array}$} \\
\hline \multicolumn{2}{|c|}{$\begin{array}{l}\text { How to cite this article: } \\
\text { Mosweu, T. \& Ngoepe, M., } \\
\text { 2019, '“Here one moment, } \\
\text { gone the next": A framework } \\
\text { for liquid communication } \\
\text { generated through social } \\
\text { media platforms in the } \\
\text { Botswana public sector', } \\
\text { South African Journal of } \\
\text { Information Management } \\
\text { 21(1), a1080. https://doi. } \\
\text { org/10.4102/sajim. } \\
\text { v21i1.1080 }\end{array}$} \\
\hline \multicolumn{2}{|c|}{$\begin{array}{l}\text { Copyright: } \\
\text { (c) 2019. The Authors. } \\
\text { Licensee: AOSIS. This work } \\
\text { is licensed under the } \\
\text { Creative Commons } \\
\text { Attribution License. }\end{array}$} \\
\hline \multirow{2}{*}{ 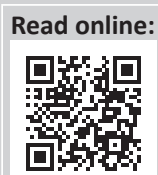 } & \\
\hline & $\begin{array}{l}\text { Scan this QR } \\
\text { code with your } \\
\text { smart phone or } \\
\text { mobile device } \\
\text { to read online. }\end{array}$ \\
\hline
\end{tabular}

Background: In Botswana, the public sector has been fully active in utilising social media platforms as part of the e-government programme, thereby generating liquid communication in the process. The content in social media platforms, which is referred to as liquid communication, is so fluid that its management becomes a challenge. This is so because one moment a post is available on a social media platform and the next moment it disappears. The unstable nature of liquid communication calls for its governance according to established national and international records management principles.

Objectives: This study utilised the principles of information governance of the Association of Records Managers and Administrators (ARMA) as a theoretical framework to examine how liquid communication generated through social media platforms is governed by the Botswana government.

Method: Qualitative data were collected through document analysis and interviews with officials from government departments concerned with the management of information.

Results: The study revealed that despite the active presence on social media by the Government of Botswana in communicating with the public, there is a lack of a framework to govern liquid communication. This resulted in weak accountability, protection, compliance, transparency and integrity, as well as retention and disposition for governance of liquid communication.

Conclusion: The study concludes by arguing that failure to manage and preserve liquid communication would result in a loss of digital heritage for the country. A framework for liquid communication governance in the Botswana public sector is suggested.

Keywords: Liquid communication; social media; information governance; public sector; botswana.

\section{Introduction and background to the problem}

Despite the fact that Internet providers offer low-cost, on-demand online storage of data, records and archives at the highest level of security, and maintain them in formats compatible with any user's system, they are neither transparent nor regulated in the cloud environment (Duranti 2015). As it pertains to the use of social media by governments, Bertot, Jaeger and Hansen (2012) argue that interaction by the government through social media introduces new challenges related to privacy, security, data management, accessibility, social inclusion, governance and other information policy issues. In recognition of the impact of information and communication technologies (ICTs) nowadays, the Botswana government has come up with various strategies and efforts to promote the use of ICTs for productivity and efficiency in its interaction with the citizens (Kalusopa \& Zulu 2009). The government has shown its commitment to provide access to Internet and connectivity in the country through reforms, such as its ICT policy to drive the implementation of technology (Batane 2013:117). As a result of this enabling platform, most people in Botswana have access to ICTs, and hence are able to use social networking sites, especially through cell phones (Statistics Botswana 2014). The ever-increasing use of social media by organisations to create and disseminate information and reaching a wide spectrum of users has been attributed to the provision of ICTs and their associated advantages in communication, as argued by Shaffer (2015:234).

Popularity of social networking sites, such as Facebook, Twitter, Pinterest, Instagram and LinkedIn, has risen in Botswana like anywhere else around the world (Masilo \& Seabo 2015). Recognising that most citizens use social media platforms, the Botswana government has also 
adopted the use of social media platforms to communicate with the public. This kind of communication has resulted in what is termed liquid communication. Zapata (2013:ii) defines liquid communication as a type of communication that can easily go back and forth between the participants involved, and that is neither restricted by time or space nor dictated by any type of social status, for example, e-mails'. As an example, a Facebook post can be shared many times by different users with their friends commenting, beyond the control of the post originator. The major challenge with liquid communication is that at one moment it is here, but may be gone the next moment. If such content is not managed properly as a record, it can be lost and thus jeopardise the cultural and documentary heritage of the country. Therefore, liquid communication that results through an interaction on social media platforms has to be managed as records, just like e-mail communication. The definition of a record as outlined in the archival legislation of Botswana is not content specific, as argued by Ngoepe and Saurombe (2016), which means that the act recognises the different formats of a record, including those which are fluid, such as records generated through the use of social media. A wide coverage is mostly encouraged especially in legal terms for other aspects not subjected to non-protection, as a result of them falling outside the realm of the legislation. The advent of technology, especially the use of social media, is critical for the proper understanding of preservation of records, as the creation, use and preservation of liquid communication can be considered intrinsic to records management, and thus need to be managed accordingly (Mosweu \& Ngoepe 2019:62). If not managed, the country may face losing its digital heritage, as pointed out by the Digital Preservation Coalition (2019:9), that digital materials have the potential to remain fluid over time, being edited or altered with ease, being damaged by media failure or decoded into human readable information in an unreliable or inaccurate manner by rendering software.

As more and more people use social media platforms to communicate, the need to capture and preserve the social media content increases (Begum 2015:i). But this does not become an easy task, as by its nature, liquid communication that results from interactions on social media platforms is not stable, as it can be shared many times beyond the control of the creating organisation. It has been revealed in a study by Masekoameng (2018) that records generated through social media were not integrated into an enterprise content management (ECM) at the South African Broadcasting Authority, as there were no guidelines for managing such records. Nonetheless, for legal and compliance purposes, the resultant records generated through the use of social media platforms particularly by the government are needed to be captured and preserved in line with both the national and international records management principles, to ensure that they are available for reference as and when required. This study used the Generally Accepted Recordkeeping Principles by the Association of Records Managers and Administrators (ARMA 2017) as a lens to investigate how liquid communication generated through the
Botswana government's use of social media was governed. The eight principles, which are accountability, transparency, integrity, protection, compliance, availability, retention and disposition, are all deemed relevant to the examination of governance of liquid communication, as Smallwood (2014:29) argues that the principles apply to all types of organisations. This study is confined to the Botswana government office that manages government information the Botswana Government Communication Information System (BGCIS) office. Apart from that, major stakeholders involved in public sector information management, such as the e-government office, the Department of Information Technology (DIT) and Botswana National Archives and Records Services (BNARS) as the custodian of public records, were included in the study. These are the main authorities concerned with information management in the country. Government ministries that do not have information management as their primary mandate are not covered by this study.

\section{Research purpose and objectives}

The main purpose of this study was to investigate how liquid communication generated through social media platforms is governed by the Botswana government with the aim to come up with a framework for governance of liquid communication. Specifically, the study sought to:

1. examine the Botswana legislative and policy framework in relation to the governance of liquid communication that results from social media usage by the Botswana government

2. assess the extent to which the Botswana government uses social media to communicate

3. determine the retention and disposition of liquid communication that results from social media usage by the Botswana government

4. establish roles and responsibilities by government officers for the governance of liquid communication that results from social media usage by the Botswana government

5. propose a governance framework for liquid communication that results from social media usage by the Botswana government.

\section{Governance of liquid communication}

As liquid communication that results from interaction of participants in social media can be shared many times beyond the control of the creating organisation, which brings in challenges of its capture and preservation, the information needs to be governed in line with records management principles to ensure that the records are available for use as and when required (Mosweu \& Ngoepe 2019:55). As defined by Gartner (2018), information governance is:

\footnotetext{
... the specification of decision rights and an accountability framework to ensure appropriate behaviour in the valuation, creation, storage, use, archiving and deletion of information, which includes the processes, roles and policies, standards and metrics that ensure the effective and efficient use of information in enabling an organisation to achieve its goals. (n.p.)
} 
Franks (2016:228) describes information governance as comprising records of life-cycle management, information risks, policy management, information access and security, information capturing and classification as well as information content. Mullon and Ngoepe (2019) extend the concept of information governance to national level rather than limiting it to organisational level. This extension can help in terms of developing national policies for governance of information including liquid communication.

This study presents a relatively new concept called 'liquid communication' in the archives and records management field, as used by Zapata (2013). Before him, researchers Choi, Im and Yoo claim to have coined the term in 2013. These three authors also point out that 'liquid communication' is based on Bauman's 'liquid modernity' theory (2000). According to Choi et al. (2013:3), the concept of liquidity was introduced about two decades ago by Bauman (2000) to explain how society has become busier and more fragmented. Bauman used the word 'solid' to signify postmodernity and to indicate 'solid' concepts, such as traditional values, customary rights, civic obligations and individual family duties. Bauman (2000) states that:

fluids ... liquids, unlike solids, cannot easily hold their shape. Fluids, so to speak, neither fix space nor bind time. While solids have clear spatial dimensions ... fluids do not keep to any shape for long and are constantly ready ... it is the flow of time that counts, more than the space they happen to occupy: that space, after all, they fill but 'for a moment'. (p. 2)

The concept of liquidity challenges the traditional notion of long-term preservation in the field of records management. By recognising that the traditional archives and records management concepts have been affected in liquid times as experienced in the postmodern era, it is possible to address challenges brought about by social media in terms of governance of liquid communication. Liquid communication generated is unstable; there is an uncertain durability and its future availability is also uncertain, which calls for its governance. DiBianca (2014) opines that the preservation of social media content is fundamentally crucial, as the failure to preserve it can have serious consequences. As a result, it was imperative to conduct this study utilising the ARMA's Generally Accepted Recordkeeping Principles, also known as 'the principles', as a lens to investigate how liquid communication generated through social media platforms is governed by the Botswana government with an aim to propose a governance framework. The constructs for the conceptual framework from some of the ARMA principles, which informed the objectives of this study, are accountability, integrity, protection, availability, retention and disposition (ARMA 2017). The ARMA principles were seen relevant for this study, as Hagmann (2013:232) contends that these eight principles take account of the foundations of relevant records and information management standards, such as the Records Management's ISO 15489-1 (2016) standard as well as best practice and legal and regulatory requirements. According to ARMA (2017), 'the principles constitute a generally accepted global standard that identifies the critical hallmarks and a high-level framework of good practices for information governance'. Published by ARMA International in 2009 and updated in 2017, the principles are grounded in practical experience and based on extensive consideration and analysis of legal doctrine and information theory. They are meant to provide organisations with a standard of conduct for governing information and guidelines by which to judge that conduct.

Liquid communication should be preserved if it possesses continuing value, as it may constitute digital heritage. There are many digital preservation strategies that organisations may use for that purpose, such as bit preservation, emulation strategy and metadata and documentation.

It has been revealed by Iron Mountain (2012:1) that most organisations do not preserve social media communication, which leaves them vulnerable to records management compliance risks. The literature shows that most countries with social media records policies and strategies are found in the developed world, such as the United States where the National Archives and Records Administration (NARA) regularly issues NARA Bulletins on guidance on managing social media records (NARA 2013). In Australia, the National Archives of Australia has guidelines for government departments on designing social media records policies (National Archives of Australia 2019), and not much was found in Africa where the literature shows only the Nigerian government, through the National Information Technology Development Agency (NITDA), having the Framework and Guidelines for the Use of Social Media Platforms in Public Institutions of 2019 (National Information Technology Development Agency 2019).

For the Botswana landscape, the National Archives and Records Services (NARS) Act of 1978 (as amended in 2007) is the main instrument that gives the Botswana National Archives and Records Services (BNARS) its mandate to collect, preserve and facilitate access to the nation's archives, as well as to provide direction in the management of government records by developing standards, procedures and providing professional advice and guidance. The NARS Act definition of a record is not content specific; thus, a record may be in any format, including those records generated through the use of social media. Notwithstanding, it has been reported by Keakopa (2018:242) that even by 2018, BNARS had not yet developed a National Records Management Policy to guide government ministries on how to manage records. This lack of national policy on records management might attribute to the many records management challenges faced by the country, such as a lack of guidelines on appraisal of records, lack of retention schedules, limited budgets and inadequate staffing in records management across the Botswana public sector, as attributed by Ngoepe and Keakopa (2011:150). 


\section{Research methodology}

The qualitative data were collected through semi-structured interviews of participants from government departments concerned with the management of social media platforms and government information. Moreover, content analysis of social media platforms and analysis of policy documents (Greener 2008:81) were undertaken in this study. The researchers used face-to-face, one-on-one as well as telephonic interviews, which took approximately $1 \mathrm{~h}$ each to collect data from the participants. The study used a case study research design because it allows for an in-depth investigation of the research problem (Yin 2009:2).

The sample of this study was purposefully selected from four Botswana government organisations, which are BGCIS, which is responsible for social media in the Government of Botswana, DIT, BNARS and Botswana Communication and Regulatory Authority (BOCRA) which are also involved in social networks and government information. Twelve participants were targeted and all were interviewed based on their experience and knowledge of the usage of Botswana government social networks and information management in the country, as it is explained by Creswell (2012:206) that in qualitative research, the researcher selects people or sites that can best help in understanding the principal phenomenon. The sample comprised public relation officers and policymakers based at BGCIS office, who manage the Government of Botswana's social media platforms, as well as records managers and archivists (BNARS), chief programmer and director of corporate services (BOCRA) and system analysts (DIT). Data were analysed thematically and the themes for analysis were generated as per the constructs of the research objectives (Creswell 2014:249). A document review of the official publications, internal and external reports, research articles, presentations, newspapers, legislation and policies expected to support the governance of liquid communication in Botswana was also undertaken. This study also analysed the Botswana government's social media pages, as directed by the participants for more information. All the findings of this study are presented thematically as per the research objectives through narratives and figures, which is in line with the argument by Yin (2011:233) that qualitative data are likely to be represented in narratives or in data arrays, such as word tables, hierarchies, matrices and other diagrams. Furthermore, verbatim quotes were used to support the themes. Abbreviations for the participants by their institutions are used instead of the names as per the ethical consideration, which requires the protection of participants' privacy and concealment of their identities.

\section{Ethical consideration}

This study obtained ethical clearance from the Science Research Ethics Review Committee of the Department of Information Science (DIS) at the University of South Africa (UNISA). The researcher also applied for a research permit from the Office of the President in Botswana, and was granted the permit to conduct this research in Botswana. During data collection, participants were asked to answer the questions on a voluntary basis, and were given the option to remain anonymous if they wished so. Apart from that, the respondents were informed that the responses were only to be used for academic research purposes. Moreover, the study used the UNISA Policy on Research Ethics (2016) to comply with ethical consideration during the research.

\section{Research findings and discussions}

This section provides an interpretation and discussion of the findings of this study presented as per the research objectives of the study.

\section{The legislative and policy framework for the governance of liquid communication}

The first objective of this study sought to determine the legislative and policy framework for the governance of liquid communication by the Botswana government, as informed by the ARMA principle of compliance. The study reviewed the existing legislation and policies deemed by this study to be in support of governance of liquid communication in Botswana. Furthermore, the participants of the study were interviewed on this objective. The document review and the interview results indicated that the legal and policy framework for the governance of liquid communication can be said to be both strong and weak. The legislative and policy framework was found to be strong, as the Government of Botswana has come up with the relevant legislation and regulations to manage information and electronic or digital records in the country as identified by the participants under the NARS Act (as amended in 2007), the Cybercrime and Computer Related Crimes Act (Government of Botswana, 2007a), the Electronic Records (Evidence) Act (Government of Botswana 2014b) and the Electronic Communications and Transaction Act (Government of Botswana 2014a). The policies available include the National Information and Communications Technology Policy (Government of Botswana 2007b) and others, such as the Computer Equipment Acceptable Use Policy (Department of Information Technology 2001a), the Anti-virus and Malware Policy (Department of Information Technology 2001b), the Removable Media Policy (Department of Information Technology 2010a), the Internet Access Policy (Department of Information Technology 2010b), the Password Policy (Department of Information Technology 2009b) and the Webcontent Publishing Framework (Department of Information Technology 2009a) (Department of Information Technology 2001a, 2001b, 2009a, 2009b, 2010a, 2010b). The weakness found was the fact that these laws are not comprehensive enough to deal with records generated in the cloud environment, such as liquid communication. The participants of this study were asked to state legislation and policies that supported liquid communication generated through the use of social media in Botswana. While participants listed the relevant legislation, others such as BGCIS3, BGCIS4, BNARS1, BNARS2, BNARS4, BNARS5 and BOCRA1 indicated that there are no policies or legislation to govern 
social media content specifically. However, participant DIT1 indicated that:

'The Ministry of Defence Justice and Security is already drawing up legal and policy instruments to govern information communication technologies. Bills aimed at amending some existing laws are being drafted, such as the amendment of the Cyber Crime Act. The Internet Access Policy, whose main purpose is to outline the proper usage of the Internet services in government, supports the use of social media. It provides guidelines and procedures of browsing the Internet and that should be abided by employees. It does not specifically addresses social media.' (DIT1, male, system analyst).

Franks and Smallwood (2014:264-268) warn that, when it comes to making decisions about capturing and preserving social media records, the legal requirements are very crucial. There are situations where records generated in cloud computing environments such as social media have been requested as evidence in courts of law (Bathurst 2016; Goh 2014; Madhava 2011; Murphy \& Fontecilla 2013). Madhava (2011:34) alludes that the courts are catching up with the deluge of social media, and judges are displaying less patience with organisations that have not properly managed their social media archives.

Before 2014, the legal and policy framework to facilitate and enable the provision of e-services in Botswana was very weak, as the legislation prohibited as opposed to encouraged the use of ICT to provide services (Keetshabe 2015). For instance, there was no provision in any Botswana law for the recognition of electronic signatures, authentication of electronic documents and admissibility of electronic evidence as records before the courts of law. Most laws have records management implications, but the main ones required, especially in the context of social media usage, such as data protection and privacy laws, are yet to be adopted.

\section{Extent to which the Botswana government uses social media to communicate}

The second objective of the study was to assess the extent to which the Botswana government used social media to communicate. This objective was informed by the ARMA principle of availability, which requires an organisation to maintain its information assets in a way that ensures their timely, efficient and accurate retrieval (ARMA 2017). The study participants outlined the Government of Botswana's social media accounts and the purposes of adopting each platform as follows:

- Social networks: Facebook was the most popular, as it had more followers than any other social media platform of the Botswana government.

- Microblogging - Twitter: The government had a Twitter account as @BWgovernment, which mostly shared the information as shared on their Facebook page 'BWgovernment'.

- Multimedia sharing: YouTube was used as a repository platform for the Botswana government's video footage taken during important events, such as the State of the
Nation Address, the Budget Speech, government projects, some of the Botswana television programmes, general election processes, etc. The use of YouTube has been common with sharing video content.

- SMS notification system: The Government of Botswana also used the SMS service to send reminders to citizens of different government services, such as the expiry date of their identity documents or driver's licences.

- Botswana Government Portal: A crucial repository platform of content, which was found to be dysfunctional at the time of the study. The platform had not been updated for the preceding five years. Nonetheless, the portal indicates that the Government of Botswana strives to exploit all appropriate e-communication platforms to provide citizens with news and information in a timely manner. The portal also directs users to the social media accounts of Facebook and Twitter of the Botswana government.

The document review undertaken in this study also reveals that the Botswana government was highly active on social media platforms as a direct result of the government's ICT policy through which it attempts to give more people access to the Internet (Batane 2013; Statistics Botswana 2014; Sunday Standard Reporter 2016). One of the participants, BOCRA1, emphasised that:

'... although the exact date for the adoption of social media in Botswana as a country was not clear, the country adopted the use of SMSs from the time of the introduction of mobile telephony in 1998. During that time, only second-generation networks (2G networks) existed with capability for voice calls and SMSs only. As networks changed to $3 \mathrm{G}$ and, lately, $4 \mathrm{G}$ and social media came on board, Batswana adopted it as an additional feature or an improvement on the SMS.' (BOCRA1, male, chief programmer).

An analysis of the social media platforms of the Botswana government was also done in this study, which gave the status of usage through the pages' metrics. Social media is different from other media because it produces measurements, which an organisation can use to track its impact and the effectiveness of its tactics and strategies. Social media platforms, such as Facebook, offer analytics in their 'insights page', and Twitter also has an 'analytics' page. The information on these analytics pages is best used for guiding strategy and reporting impact purposes (United States Department of Defense 2016).

One of the metrics tracked in this study was the level of penetration of the Botswana government's Facebook page through insight into the number of people who had any contact with the BWGovernment Facebook page by age and gender. The statistics showed that most of the people who interacted with the page were in the age bracket of 25-34 years (women at 19\%, men at 17\%). The next largest group of people was in the age bracket of $18-24$ years (11\% women, $9 \%$ men) and then those in the age bracket of 35-44 years (10\% women, $11 \%$ men). As per these results, the Botswana government's social media pages enable the government to 
reach out to the youth in the country. These age brackets denote the 'youth' according to the Botswana Revised National Youth Policy, which is between the ages of 15 and 35 (Ministry of Youth Sport and Culture 2010:5). Botswana had been considered as one of the countries with a relatively youthful population with about $46.5 \%$ young people, as per the 2011 population census (Statistics Botswana 2013).

Statistics from the BWGovernment Facebook page showing the number of people reached by country indicated that most were from Botswana (478 261), followed by South Africa (133 143) and, for some reason, the United States of America (76 829) and the United Kingdom (31 271) came before other African countries. The page insights also showed that the most people reached by city came from Gaborone (317 151), which was not surprising, as the city's population was dominated by the youth aged between 15 and 39 years who also constituted the working age group (Statistics Botswana 2014:25). This also tallies with the above statistics, which showed that the youth interacted more with the BWGovernment Facebook page than other age brackets. The second city in the country was Francistown (52 803), followed by Johannesburg (28 419), a South African city. Far below these cities was Maun (19 604) from the north-west of Botswana. The use of social media platforms by the government is commendable, as the National Archives and Records Administration (2010) states that social media platforms enable organisations to connect people to government and to share information to support business processes that both create and manage content.

\section{Retention and disposition of liquid communication}

In line with the third objective, this study investigated the retention and disposition of liquid communication that results from social media usage by the Botswana government. This objective was informed by the ARMA's principles of retention and disposition (ARMA 2017). The principle of retention calls for organisations to keep their records and information for an appropriate time, taking into account their legal, regulatory, fiscal, operational and historical requirements, while the principle of disposition requires organisations to provide secure and appropriate disposition for records and information that are no longer required to be maintained by applicable laws and the organisation's policies.

This study established that there was no documentation of the processes used to guide the transfer or disposition of social media records in Botswana, as revealed by all the public relation officers (PROs) interviewed. Consequently, there were no processes in place with the Government of Botswana for suspending disposition in the event of investigation or litigation, as this study sought to find out. The PROs had this to say:

'There are no documentations to guide the disposition of social media content'. (BGCIS1, female, public relations officer).

'Nothing has been done to deposit this with the National Archives. It will be advisable to do this'. (BGCIS2, female, policy maker).
'There is none'. (BGCIS3, female, chief public relation officer).

'We have no social media records'. (BGCIS4, male, records manager)

'There are no documented processes, as we never took social media content as records. (BGIS5, male, principal public relation officer).

However, the International Organisation for Standardisation, ISO 15489 (2016:19) sets out the following principles that should govern the destruction of records:

- Destruction should always be authorised.

- Records pertaining to pending or actual litigation or legal action or investigation should not be destroyed while that action is underway or anticipated to arise.

- Records destruction should be carried out in a way that ensures complete destruction, and which complies with any security or access restrictions on the record.

- Destruction, like any disposition action, should be documented.

\section{Roles and responsibilities for the governance of liquid communication}

The fourth objective of this study was informed by the ARMA's principle of accountability. On the issue of roles and responsibilities, the International Records Management Standards, ISO 15489 (2016:9), states that the decisions about creating, capturing and managing records are business decisions informed by identified records requirements and an assessment of risks, and therefore:

- The decisions should be authorised by the relevant business manager and documented.

- The responsibilities should be designated to all personnel who create and use records as part of their work, and be reflected in job descriptions and similar statements, where appropriate.

- The designation of the responsible individuals may be assigned by law.

- Specific leadership responsibility for the management of records should be assigned to a person with appropriate authority, such as a senior manager.

The monitoring of social media pages through responding to fan questions, comments and other feedback forms a vital activity, as social media platforms such as Facebook are used to engage the target audience in a two-way interaction and communication (United States of America Centre for Disease Control and Prevention 2012:4). This study sought to discover the responsibilities for monitoring and removing the content of the social media accounts of the Government of Botswana. The participants revealed that super administrators (upper level) had the responsibilities to monitor and remove the content. As the social media pages of the Botswana government are meant to publish government business, content that is normally monitored or removed from the pages includes advertisements, private materials, offensive content and information that has already served its purpose, like government job adverts. 
The study revealed that social media pages of the Government of Botswana were administered by public relations officers, while records managers were not involved in any way with the government's social media efforts. This may be attributed to the fact that social media use by the government was mainly considered as a marketing tool, and there was no consideration for managing the resultant communication as records, as the government had no plans regarding this. The chain of responsibilities is in a manner that the assistant public relations officers (APROs) report to the principal public relations officers (PPROs), who further report to the chief principal public relation officer (CPRO). The participants revealed that the social media pages of the Botswana government received content from other ministries and departments. This content covers updates on events coverage and press releases as well as government job vacancies adverts. The submissions were made by PROs from the respective ministries and departments. The content should be submitted with a signed version and an MS Word format electronic version ready for publishing. All submissions were submitted through the Public Relations (PR) office and then sent to the government communication's office e-mail (bgcis@gov.bw) for consideration to be published on social media. From the interviews undertaken with the PROs, this study revealed that the responsibilities for monitoring the social media pages of the Botswana government rested with the super administrator, who was a person with upper level responsibilities. When explaining how this works, participant BGCIS1 said:

'[T]he administrators of the social media pages of the Botswana government constantly receive requests from institutions and private individuals in the country to have their materials published on the government's social media platforms. As a result, there is need to regulate such requests, as the government's social media pages are intended to publish government business.' (BGCIS1, female, public relations officer).

\section{Framework for the governance of liquid communication generated through social media}

The last objective of this study sought to propose a governance framework for liquid communication that results from social media usage by the Botswana government. This section presents the proposed framework. This study has established that although the Botswana government has adopted and used social media platforms since 2011, there were no formalised processes and procedures for the governance of liquid communication. The lack of formalised processes and procedures for the governance of liquid communication poses risks for the government relating to legal and compliance requirements. The proposed framework in Figure 1, which is by no way prescriptive, would assist the government in ensuring that liquid communication generated through its interaction with the citizens is captured and preserved to ensure that it is available for use as and when required. This would also enable the Government of Botswana to achieve its intended goals in the use of social media platforms.

\section{Social media}

This study acknowledges social media, including social networking applications, such as Facebook and Google+, microblogging services, such as Twitter, blogs, wikis and media-sharing sites, such as YouTube, where official government business takes place. This was shown from the data collection done in this study through a review of the social media pages of the Botswana government as well as the associated metrics. The interaction between the government and the citizens results in liquid communication. As liquid communication may be requested as evidence before the courts of law in Botswana, there is a need for liquid communication governance for legal and compliance purposes.

\section{Liquid communication}

This study terms liquid communication as records generated by the government on social media for customer service, access to information and direct community involvement needs. Liquid communication generated through the use of social media includes status updates, shares, tweets, re-tweets, blogs, posts, comments and messages. By applying the concept of liquidity to records management, it is possible to capture or govern this liquid communication. Although this study did not reveal any incidents where information was disclosed or lost inappropriately or inadvertently,

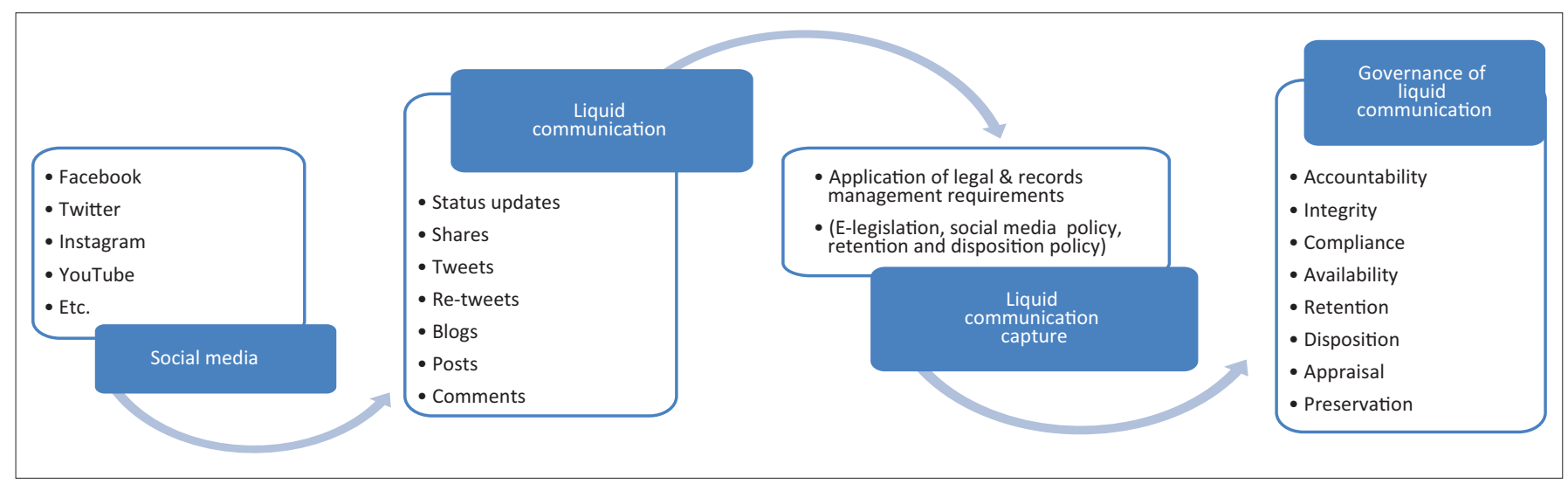

Etc., et cetera.

FIGURE 1: Framework for the governance of liquid communication generated through social media. 
especially because liquid communication was not taken to require any governance, it revealed that government activities on social media, such as status updates, shares, tweets, re-tweets, blogs, posts and comments, generated the fragile liquid communication. Liquid communication generated through the use of social media is unstable; there is an uncertain durability, and its future availability calls for its governance.

\section{Capturing of liquid communication}

The contention of this study is that liquid communication generated through the use of social media is evidence of business activities and should be managed accordingly for other business requirements, as supported by the legal framework. This framework requires that the records management requirements in an organisation should be extended to the management of liquid communication when it is proven that the records possess the characteristics of authenticity, reliability, integrity and usability to be considered authoritative evidence of business events or transactions, and to fully meet the requirements of the business (ISO 15489-1 2016). This study has revealed that social media communication by the Botswana government was not captured and managed, as revealed under objective two of this study. The moment an organisation is satisfied that the liquid communication generated through social media has the above characteristics, the liquid communication should be captured and managed according to the organisation's records management requirements. The communication that goes on between the government and the citizens should be retained for reasons of accountability and transparency under records management requirements and legal requirements. The International Records Management Standards ISO 15489 (2016:16) calls for processes for creating, capturing and managing records to be integrated into procedures and applicable systems, including records systems, and should involve the use of records controls, where appropriate. These processes include the following:

- Creating records

- Capturing records

- Classification and indexing

- Access control

- Storing records

- Use and reuse

- Migration or conversion

- Disposition

The potential weakness of the framework is that the legal and records management requirements vary from country to country according to the existing laws and established records management requirements that regulate information governance in each country. Notwithstanding the above, the governance of liquid communication requires the existence of a social media policy to ensure a formalised process for the same. This policy should regulate the control, creation, receipt, transmission, maintenance and disposition of liquid communication. It is through this policy that a records management system is established to keep track of social media activities. The social media policy would facilitate compliance with the guidelines of national archives and records services for records management and archiving, as well as compliance with applicable laws and other binding policies in the country.

\section{Governance of liquid communication}

Governance of liquid communication in this study was premised upon the Generally Accepted Recordkeeping Principles of ARMA (ARMA 2017). The eight principles are outlined as: accountability, transparency, integrity, protection, compliance, availability, retention and disposition. As these principles describe effective information governance, they were considered to be relevant for this study, as they apply to all types of organisations, in all types of industries, including government or the public sector (Franks \& Smallwood 2014:29). These ARMA principles apply in the governance of liquid communication generated through the use of social media as follows: In order for the framework for the governance of liquid communication generated through social media to effectively work, it requires liquid communication to be captured and preserved according to the records management and legal requirements. This is because liquid communication, in its nature on social media platforms, is neither fixed by space nor bound by time. These activities require a crossfunctional approach where the roles and responsibilities of the PROs, IT application analysts, records managers and other stakeholders are consolidated and documented.

The need for governance of liquid communication was revealed by the literature and results of this study, as discussed under all the objectives of this study guided by the ARMA principles (ARMA 2017).

\section{Conclusion}

This study investigated the legislative and policy framework for the governance of liquid communication generated using social media by the government in terms of legislation, such as the National Archival law, the Electronic Records (Evidence) Act, the Cybercrime and Computer Related Crimes Act and the National ICT policy. As these instruments were not found to be comprehensive enough to deal with records generated in a cloud environment, such as liquid communication, the need for a social media policy was recommended as a matter of urgency. Social media policies have been adopted mostly led by archival institutions in countries such as the United States of America and Australia (NARA 2013, National Archives of Australia 2019), while the literature reviewed showed none amongst the African countries. A social media policy was required to guide the creation, receipt, transmission, maintenance and disposition of liquid communication. Measures to ensure the integrity of liquid communication generated through the use of social media by the Botswana government were lacking. This study found that because liquid communication was not managed as records, audit trail requirements were not formalised and 
documented to ensure that liquid communication remains authentic. The study also revealed that issues of retention and disposition of liquid communication were also not documented and formalised. Although the roles and responsibilities of PROs were specified, this was not the case with records managers and other government units and departments. As a result, this study recommended the capturing and governance of liquid communication generated through the use of social media by the Botswana government. Failure to manage and preserve these records would result in a loss of digital heritage for the country. This study suggests few more areas of research, such as:

- The contextualisation and instantiating or implementation of the proposed framework at other institutions, including governments or corporate bodies.

- The comparison or benchmarking of the maturity of the governance of liquid communication amongst governments, for example within Southern Africa, using the proposed framework and/or the ARMA Information Governance Maturity Model.

- The provision of assurance over the liquid communication records generated by utilising social media, the limitation of scope due to public cloud-based social media platforms and the levels of assurance required based on a combined assurance model.

\section{Recommendations}

Based on the findings, this study makes the following recommendations:

- Legislative and policy framework - This study found that although the legislative and policy framework for the governance of liquid communication generated through the use of social media by the government did exist, the existing laws and policies are not comprehensive enough to deal with records generated in a cloud environment, such as liquid communication. As a result, this study recommends that the National Archives and Records Services Act of 1978 (amended in 2007) be strengthened with provisions that guide the management of records generated in a cloud environment, such as liquid communication. A social media policy should be adopted to standardise the governance of liquid communication across the public sector. This policy would be used to control the creation, receipt, transmission, maintenance and disposition of liquid communication. It would also necessitate the establishment of a records management system to keep track of social media activities to comply with the guidelines of national archives and records services for records management and archiving, and with applicable laws and other binding policies.

- The extent of social media usage by the Botswana government This study found that although the Government of Botswana ran different social media pages, Facebook was maintained more than others, such as YouTube, Instagram and Google+. It would be ideal for the Government of Botswana to maintain all their social media pages, and consequently govern liquid communication generated even under those platforms. As it is established that the government had adopted the use of social media platforms without clear policies and guidelines, this study recommends the adoption and implementation of strategies on the use of social media by the government. This would enable the formalisation of the use of social media by the government for transparency and accountability, and to increase citizens' opportunities to participate and collaborate in decision-making. The framework for governance of liquid communication generated through the use of social media proposed by this study calls for the application of legal and records management requirements in order to ensure that liquid communication is captured and preserved accordingly.

- Retention and disposition of liquid communication-Objective number four of this study investigated how liquid communication generated through social media in Botswana was retained and disposed of by the Botswana government. This study found that despite the active usage of social media platforms in generating liquid communication by the Botswana government, issues of retention and disposition of liquid communication were also not documented and formalised. This study recommends a retention schedule for liquid communication to be used to: document the recordskeeping requirements and procedures, identify how records are to be organised and maintained and identify and record responsibilities of individuals. It is also recommended that BNARS as a public body entrusted with the management of public sector records should guide the BGCIS office in the development of guidelines for the retention and disposition of liquid communication.

- Roles and responsibilities for the governance of liquid communication - This study revealed that only the roles and responsibilities of PROs were defined as the administrators of the social media pages of the Botswana government; other crucial individuals, units and departments were not specified. Therefore, this study recommends a crossfunctional approach to the governance of liquid communication in Botswana. The roles and responsibilities of IT application analysts, records managers, the BNARS, the DIT, the BOCRA and the e-government office in the governance of liquid communication should clearly be spelt out and documented. This study further recommends that records managers should be responsible for aspects of managing liquid communication, including the design, implementation and maintenance of records systems and their operations, and for training users on their responsibilities and records systems operation.

\section{Acknowledgements}

The authors acknowledge the financial support provided by the University of South Africa and the National Research Foundation.

\section{Competing interests}

The authors declare that they have no financial or personal relationships that may have inappropriately influenced them in writing this article. 


\section{Author's contributions}

T.M. and M.N. conceptualised the study. T.M. conducted the literature review, collected data and wrote the article. M.N. supervised the study.

\section{Funding}

This study was made possible by Research Development Grant for InterPARES Team Africa Project by the National Research Foundation.

\section{Data availability statement}

Data are available from authors on request.

\section{Disclaimer}

The views and opinions expressed in this article are those of the authors and do not necessarily reflect the official policy or position of any affiliated agency of the authors.

\section{References}

Association of Records Managers and Administrators (ARMA), 2017, Generally accepted recordkeeping principles, viewed 18 December 2017, from http://www. accepted recordkeeping
arma.org/principles.

Batane, T., 2013, 'Internet access and use among young people in Botswana', International Journal of Information and Education Technology 3(1), 117-119.

Bathurst, T.F., 2016, 'Tweeters, posters and grammars beware: Discovery and social media evidence', 10th information governance \& eDiscovery summit, viewed 13 January 2018, from http://www.supremecourt.justice.nsw.gov.au/Documents/Publications/ Speeches/2016\%20Speeches/Bathurst\%20CJ/Bathurst_20160621.pdf.

Bauman, Z., 2000, Liquid modernity, viewed 12 December 2017, from https:// giuseppecapograssi.files.wordpress.com/2014/01/bauman-liquid-modernity.pdf.

Begum, R.A., 2015, Preserving social media: A case study at LTU archives, Luleå University of Technology, Luleå.

Bertot, J.C., Jaeger, P.T. \& Hansen, D., 2012, 'The impact of polices on government social media usage: Issues, challenges, and recommendations', Government Information Quarterly 29, 30-40. https://doi.org/10.1016/j.giq.2011.04.004

Choi, K.S., Im, I. \& Yoo, Y., 2013, Liquid communication: An analysis of the impact of mobile micro-blogging on communication and decision-making, viewed 15 January 2018, from http://aisel.aisnet.org/cgi/viewcontent.cgi?article=1301\& context=icis 2013 .

Creswell, J.W., 2014, Research design: Qualitative, quantitative, and mixed methods approaches, Sage, Los Angeles, CA.

Creswell, J.W., 2012. Educational research, Sage, Los Angeles, CA.

Department of Information Technology, 2001a, Computer equipment acceptable use policy. Ministry of Transport and Communications, Gaborone.

Department of Information Technology, 2001b, Anti-virus and malware policy, Ministry of Transport and Communications, Gaborone.

Department of Information Technology, 2009a, Web-content publishing framework, Ministry of Transport and Communications, Gaborone.

Department of Information Technology, 2009b, Password policy, Ministry of Transport and Communications, Gaborone.

Department of Information Technology, 2010a, Removable media policy, Ministry of Transport and Communications, Gaborone.

Department of Information Technology, 2010b, Internet access policy, Ministry of Transport and Communications, Gaborone.

DiBianca, M., 2014, Discovery and preservation of social media evidence, viewed 10 June 2018, from http://www.americanbar.org/content/dam/aba/publications/ blt/2014/01/social-media-evidence-201401.authcheckdam.pdf.

Digital Preservation Coalition, 2019, Digital preservation handbook, viewed 13 April 2019, from https://www.dpconline.org/docs/digital-preservation-handbook2/ 1552-dp-handbook-digital-preservation-briefing/file.

Duranti, L., 2015, 'Special issue: Data, records, and archives in the cloud', Canadian Journal of Information and Library Science 39(2), 91-96.

Franks, P., 2016, 'Information governance', in L. Duranti \& P. Franks (eds.) Encyclopaedia of archival science, Rowman \& Littlefield, New York.

Franks, P. \& Smallwood, R.F., 2014, 'Information governance for social media', in R.F. Smallwood (ed.), Information governance, John Wiley \& Sons, New Jersey.

Gartner Inc., 2018, Information Governance, viewed 10 October 2018, from http:// www.gartner.com/it-glossary/information-governance.
Goh, E., 2014, 'Clear skies or cloudy forecast? Legal challenges in the management and acquisition of audio-visual materials in the cloud', Records Management Journal 24 (1), 56-73. https://doi.org/10.1108/RMJ-01-2014-0001

Government of Botswana, 1978, National archives and records services act cap 59:04, Government Printer, Gaborone.

Government of Botswana, 2007a, Cybercrime and computer related crimes act, Government Printer, Gaborone.

Government of Botswana, 2007b, National information and communications technology policy, viewed 16 December 2017, from http://www.bits.org.bw/wpcontent/uploads/2016/05/Final-Revision-MCST-Maitlamo-Policy.pdf.

Government of Botswana, 2014a, Electronic communications and transactions act, Government Printer, Gaborone.

Government of Botswana, 2014b, Electronic records (evidence) act, Government Printer, Gaborone.

Greener, S., 2008, Business research methods, Ventus Publishing, Telluride.

Hagmann, J., 2013, 'Information governance-Beyond the buzz', Records Management Journal 23(3), 228-240. https://doi.org/10.1108/RMJ-04-2013-0008

International Organization for Standardization, 2016, 'Information and documentation records management', ISO 15489-1.

Iron Mountain, 2012, Taking the rogue out of social media, viewed 12 March 2018, from $\mathrm{http}: / / w w w . i r o n m o u n t a i n . c a / e n / r e s o u r c e s / w h i t e p a p e r s / t / t a k i n g-t h e-r o g u e-o u t-$ of-social-media.

Kalusopa, T. \& Zulu, S., 2009, 'Digital heritage material preservation in Botswana: Problems and prospects', Collection Building 28(3), 98-107. https://doi. org/10.1108/01604950910971125

Keakopa, S.M., 2018, 'Management of public sector records and archives in Botswana', in P. Ngulube (ed.), A handbook of research and heritage management, pp. 235-256, IGI Global, Hershey.

Keetshabe, A., 2015, Developing cyber legislation in Botswana: An update, viewed 13 December 2017, from http://www.cit.co.bw/downloads/elegislation $\% 20 \mathrm{in} \% 20$ botswana\%20-\%20keetshabe.pdf.

Madhava, R., 2011, 10 Things to know about preserving social media, viewed 10 August 2017, from http://content.arma.org/IMM/Libraries/SeptOct_2011_PDFs/ IMM_0911_10_things_to_know_about_preserving_social_media.sflb.ashx.

Masekoameng, M.F., 2018, Integration of social media records into enterprise content management at the South African Broadcasting Corporation in the Limpopo province of South Africa, University of South Africa, Pretoria.

Masilo, B. \& Seabo, B., 2015, 'Facebook: Revolutionising electoral campaign in Botswana', Journal of African Elections 14(2), 110-219.

Mosweu, T. \& Ngoepe, M., 2019, 'Governance of liquid communications in the Botswana public sector: Neither restricted by time nor space', in C.T. Chisita \& A.M. Rusero (eds.), Exploring the relationship between media, libraries, and archives, pp. 53-69, IGI Global, Pennsylvania, PA.

Ministry of Youth, Sport and Culture, 2010, Revised national youth policy, viewed 15 July 2018, from http://www.youthpolicy.org/national/Botswana_2010_ National Youth_Policy.pdf.

Mullon, P.A. \& Ngoepe, M., 2019, 'A integrated framework to elevate information governance to national level in South Africa', Records Management Journal 29 , 103-116. https://doi.org/10.1108/RMJ-09-2018-0030

Murphy, J.P. \& Fontecilla, A., 2013, 'Social media evidence in government investigations and criminal proceedings: A frontier of new legal issues', Richmond Journal of Law and Technology 19(3), 1-30.

National Archives of Australia, 2019, 'You social media policy, What about records', viewed 13 March 2019, from http://www.naa.gov.au/information-management/ managing-information-and-records/types-information/social-media/socialmedia-policy/index.aspx.

National Archives and Records Administration, 2010, 'A report on federal Web 2.0 use and record value', viewed 20 July 2018, from https://www.archives.gov/files/ records-mgmt/resources/web2.0-use.pdf.

National Archives and Records Administration, 2013, 'Bulletin 2014-02: Guidance on managing social media records', viewed 05 June 2018, from https://www. archives.gov/records-mgmt/bulletins/2014/2014-02.html.

National Information Technology Development Agency, 2019, 'Framework and guidelines for the Use of Social Media Platforms in Government Establishments', viewed 23 July 2019, from https://nitda.gov.ng/wp-content/uploads/2019/01/ Framework $\% 20$ and $\% 20$ Guidelines $\% 20$ for $\% 20$ the $\% 20$ Use $\% 20$ of $\% 20$ Social $\% 20$ Media\%20Platforms\%20in\%20Public\%20Institutions.pdf.

Ngoepe, M. \& Keakopa, S., 2011, 'An assessment of the state of national archival and records systems in the ESARBICA region - A South Africa-Botswana comparison' Records Management Journal (21), 145-160. https://doi.org/10.1108/09565 691111152071

Ngoepe, M. \& Saurombe, A., 2016, 'Provisions for managing and preserving records created in networked environments in the archival legislative frameworks of selected member states of the Southern African Development Community', Archives and Manuscript 44(1), 24-41. https://doi.org/10.1080/01576895.2015. 1136225

Shaffer, E., 2015, 'Information policy', in L. Duranti \& P. Franks (eds.), Encyclopaedia of archival science, pp. 234-235, Rowman \& Littlefield, New York.

Smallwood, R.F., 2014, Information governance, John Wiley \& Sons, New Jersey.

Statistics Botswana, 2013, 'Population and housing census 2011', viewed 20 September 2018, from http://www.statsbots.org.bw/sites/default/files/ publications/Population $\% 20$ and $\% 2$ Housing $\% 2$ CCensus $\% 202011 \% 20 \% 20$ Dissemination\%20seminar\%20report.pdf. 
Statistics Botswana, 2014, 'Botswana household access and individual use of Information \& Communication Technologies - 2014', viewed 17 August 2017, from Information \& Communication Technologies - 2014', viewed 17 August 2017, from
http://www.statsbots.org.bw/sites/default/files/publications/Botswana\%20 http://www.statsbots.org.bw/sites/default/files/publications/Botswan

Sunday Standard Reporter, 2016, 'Botswana has highest rates of Facebook use in Africa', Sunday Standard Newspaper, 29 March, viewed 18 March 2017, from Attp://www sundaystandard info/botswana-has-highest-rates-facebook-useafrica.

United States Department of Defense, 2016, 'Memorandum for military service public affairs chiefs', viewed 15 July 2018, from https://www.defense.gov/Portals/1/ Documents/pubs/Forging-Two-New-Links-Force-ofthe-Future-1-Nov-16.pdf.
United States of America Centre for Disease Control and Prevention, 2012, 'Social media guidelines and best practices', viewed 10 March 2018, from https://www. cdc.gov/SocialMedia/Tools/guidelines/pdf/FacebookGuidelines.pdf.

Yin, R.K., 2009, Case study research: Design and methods, 4th edn., Sage, New Delhi.

Yin, R., 2011, Qualitative research from start to finish, The Guilford Press, New York.

Zapata, D.D., 2013, 'Liquid communication: How FC Barcelona is spreading sentiment Blaugrana one drop at a time', viewed 17 May 2017, from http://digitool.library. colostate.edu/webclient/DeliveryManager/digitool_items/csu01_storage/2013/ 10/23/file_1/247896. 